\title{
Numeracy practices and vulnerability in old age: interdependencies and reciprocal effects
}

\author{
Christine Zeuner ${ }^{1} \cdot$ Antje Pabst $^{1} \cdot$ Melanie Benz-Gydat $^{1}$
}

Accepted: 22 December 2019 / Published online: 1 February 2020

(c) The Author(s) 2020

\begin{abstract}
In this paper we discuss individual numeracy practices of older people (age cohort 65 and above), concentrating on findings concerning interdependencies of numeracy practices and vulnerability and their reciprocal effects, drawing on first results of a qualitative, explorative study entitled 'Numeracy as social practice in the course of time'. For this paper, we examine the issue of vulnerability in relation to dimensions such as financial and economic situation, health and social embeddedness. Drawing on the concept of 'numeracy as social practice' according to Baker and Street (International encyclopedia of adult education and training, Pergamon Press, Oxford, 1996), we focus on the strategies of older people using numeracy practices and skills to lead independent, self-determined and autonomous lives, to experience individual life satisfaction and to avoid vulnerable situations. The findings, derived from in-depth interviews with the above-mentioned cohort, show that various meanings are attributed to numeracy practices in response to certain requirements and needs concerning personal wellbeing, as well as anticipating developments such as biographical transitions. We discuss how mathematical knowledge and skills are applied when transformed into individual numeracy practices. Our findings, which demonstrate the creative and meaningful use of numeracy practices according to personal needs, are then discussed within the scope of formal teaching and learning processes in basic adult education.
\end{abstract}

Keywords Numeracy as social practice $\cdot$ Vulnerability in older age $\cdot$ Financial and economic situation $\cdot$ Health $\cdot$ Social embeddedness · Qualitative study

\section{Introduction}

In this paper we discuss the interrelationship between old age, vulnerability and numeracy practices, drawing on qualitative data from a current study entitled 'Numeracy as social practice in the course of time', which explores the use of numeracy practices by older people (birth cohorts 1926-1955), taking into account the meanings they individually attribute to these practices. ${ }^{1}$ In our study we therefore ask how older people use numeracy practices throughout

Christine Zeuner

zeuner@hsu-hh.de

Antje Pabst

antje.pabst@hsu-hh.de

Melanie Benz-Gydat

benz-gydat@hsu-hh.de

1 University of the German Federal Armed Forces Hamburg, Chair of Adult Education, Helmut-Schmidt-University, Holstenhofweg 85, 22043 Hamburg, Germany their lives, and we investigate the significance of numeracy for individuals. Our approach draws on the following theoretical frameworks: on the one hand, we analyse and interpret the qualitative data regarding the concept of numeracy as social practice according to Baker and Street (1996), as well as the aspect of vulnerability. On the other hand, we are using the subject-oriented point of view on learning according to Klaus Holzkamp's learning theory (1993) as an interpretative framework. Therefore we analyse the individual use and application of mathematical knowledge and skills of older people that have been learned earlier in life. The analysis also provides information concerning individual aims and objectives for ongoing learning processes by considering individual strategies and resources. The results of our study can also be discussed with regard to aspects of learning within settings of basic adult numeracy education. Considering aspects of the subjectively oriented learning

\footnotetext{
1 The project is part of the Hamburg Numeracy Research Network, consisting of six subprojects. It is funded by the Landesforschungsförderung Hamburg from July 2017 to December 2020.
} 
theory in facilitating processes within basic adult education settings, means carefully considering the learners' practices and meanings. Facilitators, however, should be aware of the individual resources that learners draw on.

In the light of our research, the review of the literature regarding numeracy and mathematics concerning adults shows a lack of research in relation to people older than 65 years of age. They are subjects of the 'CiLL study' (Competences in Later Life) (Friebe et al. 2014; Friebe and Schmidt-Hertha 2013), but mathematics is only one topic among several others. Therefore, numeracy practices by older people are rarely looked at. First results of our study show that these generations use numeracy practices in different ways and are thus able, among other things, to reduce the possible risks of vulnerability at this stage of life.

The paper is focused on the following questions:

- How do numeracy practices minimise the risk of vulnerability in old age?

- In what contexts do older people apply numerical skills and practices in order to avoid or minimise the effects of vulnerability?

- How does age affect the use of numeracy practices?

- What are the individual and social meanings of numeracy practices?

To answer these questions, the paper is structured as follows. Since numeracy is a complex and heterogeneous concept, the literature review in Sect. 2 outlines the current state of research and discussion. There, we also discuss our approach to the research. In Sect. 3, we present the theoretical framework developed for this contribution. In Sect. 4, we discuss our methodological and analytical approach. Section 5 presents the results of our analysis as well as their interpretation with regard to vulnerability in old age and its minimisation through the usage of numeracy skills and practices, along with a discussion of these findings. Section 6 draws conclusions concerning the practice of basic numeracy in adult education.

\section{Literature review}

In recent years, many dimensions of numeracy have been discussed in scientific discourse and research and, according to Geiger et al. (2015), different concepts of numeracy related to adults have been developed. On the one hand, numeracy is presented from an international perspective, using large-scale longitudinal methodological approaches such as the Programme for the International Assessment of Adult Competencies (PIAAC). Therein, key competences concerning reading, writing, and computational as well as mathematical skills of adults were assessed and measured.
On the other hand, everyday uses of numerical skills and practices of adults are examined, mostly drawing on qualitative research methods such as biographical or ethnographical approaches (Yasukawa et al. 2018). These studies examine numeracy in different social domains such as work/employment, everyday life or health, and digitalisation, and they take different cultural contexts into account.

\subsection{Numeracy and the 'Programme for the International Assessment of Adult Competencies' (PIAAC)}

At the turn of the century the following arguments dominated the international discourse: a lack of literacy and numeracy competences heavily influenced the ability of people to successfully manage lifespan transitions from school to work and later to retirement (Paulos 2000; Bynner and Parsons 2006). This lack also affects personal and societal success with regard to earnings, employment, education, further learning, etc. Positive individual outcomes were expected concerning health and the accumulation of social capital (Gal et al. 2009). Furthermore, the relevance of numeracy was discussed in a broader economic and societal context, both in maintaining economic competitiveness and enhancing personal chances of employability ( $\mathrm{Gal}$ et al. 2009), and in being critical for informed citizenship participation and therefore supporting democracies ( $\mathrm{Gal}$ et al. 2009).

In this context, the PIAAC study was launched by the OECD in 2012, with the aim of identifying and measuring levels of literacy and numeracy and the "differences within and between countries" (Gal et al. 2009, p. 14). The main objectives of the PIAAC study were to provide information to policymakers and key stakeholders at national and international levels in order to support education policy measures (Gal et al. 2009). The PIAAC concentrates on numeracy competences of adults aged 16-65 years. Numeracy is defined as "the ability to access, use, interpret, and communicate mathematical information and ideas, in order to engage in and manage the mathematical demands of a range of situations in adult life" (Gal et al. 2009, p. 21).

In addition to numeracy, the PIAAC also describes numerate behaviour. Being able to "manage a situation or solve a problem in a real context; it involves responding to information about mathematical ideas that may be represented in a range of ways" (Gal et al. 2009, p. 21). It is "founded on the activation of several enabling factors and processes" (Gal et al. 2009, p. 21), such as mathematical knowledge, understanding and problem-solving skills, literacy skills, beliefs and attitudes, numeracy-related practices and experiences as well as context and world knowledge. Accordingly, numerate behaviour has four facets (context, responses, mathematical content, information and ideas, 
and finally representations) which characterise situations or problems for people to manage or solve (Gal et al. 2009; Tout and Gal 2015).

1. The context, as a first facet, includes the purpose or aim of a calculation action that can take place in everyday life, at work, in society or in training activities.

2. The second facet implies that people must respond to a task in some way, for example by making an estimate or measuring, modelling and communicating about the activity.

3. In the third facet, there are four broad categories of mathematical content, information or ideas: quantity and number; data and chance; patterns, relationships and changes; and dimension and form.

4. The fourth facet indicates how mathematics can appear for people and describes various representations.

While the PIAAC does not consider our target grouppeople aged 65 and older - we find corresponding research questions in the German 'CiLL study' (Competences in Later Life) (Friebe and Schmidt-Hertha 2013; Friebe et al. 2014). The approach was twofold: the same cognitive assessment methodology as in PIAAC was used in order to measure multiple life domains such as literacy, numeracy, and problem-solving in technology-rich environments. A large sample of older people $(\mathrm{N}=1325)$, aged between 66 and 80, was assessed regarding their mathematical competences and mathematical skills (Friebe et al. 2014). A small qualitative study was added as a case study, in which were interviewed 42 elderly people who described their everyday use of competences in multiple life domains, including everyday use of basic mathematical skills.

According to the results of the CiLL study, complex mathematical calculation methods are hardly practised by older people, whereas they reported using basic mathematical skills for price calculations, checking bank statements, measuring drug dosages, supervising prescriptions on a daily basis, and so on (Knauber and Weiß 2014). Selected sociodemographic factors show further differences. Older people with academic degrees (1\%) have a high level of mathematical competence. The majority of the elderly population reach level two or three, at which tasks can be processed with several steps, and statistics can be interpreted as graphics. In addition, men perform better than women, which is usually due to higher formal qualifications. There are also differences related to age; older people on average perform worse than younger ones (Knauber and Weiß 2014).

In the PIAAC studies, everyday application contexts of adult numerical skills are taken into account in the modelling of test tasks. Nevertheless, large-scale studies measure the handling of numerical requirements in a standardised and comparable way for cross-cultural benchmarking concerning different countries. Cognitive dimensions are the focus of attention, but the individual perspectives of people on numeracy cannot be depicted. In addition, numeracy is applied differently in distinct social and cultural domains and shows various forms of representation. This perspective is examined in more detail in the following section.

\subsection{Further perspectives on numeracy}

Complementing the large-scale studies, qualitative, rather ethnographically oriented studies exist, which study numeracy in various social domains or with regard to cultural aspects, and which tackle, among other issues, the following aspects (Geiger et al. 2015).

Workplace numeracy encompasses looking at applications of mathematical skills and knowledge in the workplace (e.g. Zevenbergen et al. 2009; Yasukawa 2018), within the context of vocational education and training (Straesser 2007), and looking at the skills needed to cope with digital society, which is called techno-mathematical literacy (Hoyles et al. 2010).

Already in 1982, the Cockcroft Report advocated statistical literacy as an educational goal. The aim is to educate people about statistical information such as averages, samples, probabilities, etc., thereby enabling them to distinguish where opinions are influenced or deceived (Watson and Callingham 2003). According to Houston (2009), a so-called financial competence involves personal financial knowledge and the application of this knowledge to plan and execute financial actions and to make appropriate decisions.

Health numeracy refers to skills and abilities which are necessary to make appropriate health decisions, to understand health information concerning health plans, treatments and medication instructions, and to make informed health care choices (Institute of Medicine 2014). Peters et al. (2013) differentiate two aspects of numeracy which are useful in making health decisions: education-based numeracy skills and emergent decision-based numeracy abilities. The former concern basic skills such as reading numbers, counting, and telling time. The latter refers to more advanced skills such as computational, analytical and statistical skills needed to make informed health decisions. So far, health numeracy focuses on the question of how these different skills can be measured according to skill level; however, numerate behaviour concerning health issues also depends on the context in which it is used (Institute of Medicine 2014).

Concepts of critical numeracy ask about the impact of interests and power relations embedded in numeracy concepts and usage (Cockcroft 1982; Yasukawa 2018). This perspective argues for an emancipatory or critical ability which reflects how numeracy is exposed to social or ideological criticism-a perspective which might question authorities (Zevenbergen 1995; Ernest 2002). 
A critical view is also taken by studies that can be summarised under the term numeracy as social practice. According to Yasukawa et al. (2018), the concept can be traced back to four theoretical origins and research lines. One major strand is known as the situational perspective on cognition and is defined as "what people do in daily, weekly and ordinary cycles of activity" (Lave 1988, p. 15). Practices include cultural and social norms of participation as well as routine sets of activities. Another influence on numeracy as social practice is the cultural-historical theory of activity (CHAT). This concept goes back to Vygotsky (1986) and asks how social practices are maintained even in times of disturbances. The third influence on numeracy as social practice goes back to ethnomathematics. For Gerdes (1994), this is a field of research that aims to influence teaching mathematics and curricula in an emancipatory way. This vision is shared by others such as D'Ambrosio (1999), Zaslavsky (1994) and Borba (1990). The fourth influence on numeracy as social practice was derived from the concept of literacy as a social practice, developed by the anthropologist Brian Street (2001). The term 'literacy' refers to any form of social communication or practice that requires a semiotic code. This concept of literacy as social practice, represented by Heath (1982), Street (2001) and Barton and Hamilton (1998), deals with different ideas of reading and writing. Literacy as social practice not only refers to technical skills in order to decode and encode signs, it also focuses on literacy practices in different social domains. Our study is based on this approach.

\section{Theoretical framework}

The presentation of our findings is based on two different theoretical approaches. Our theoretical framework concerns the concept of numeracy as social practice, and we also draw on aspects discussing vulnerability in old age.

\subsection{Numeracy as social practice: theoretical approaches and models}

Numeracy as social practice focuses on usage and reasoning. As stated in Sect. 2.2, the model of numeracy as social practice is closely linked to the model of literacy as social practice. Both models emerged in the early 1990s. Within the context of new literacy studies, both literacy and numeracy were considered forms of action, embedded in various social and cultural contexts, and often characterised by unequal power relations. Numeracy and literacy are embedded in social structures and organisations, influencing the usage and their status (Heath 1982; Street 1984; Barton and Hamilton 1998). Baker and Street (1996) define two models of literacy and numeracy as social practices, distinguishing between the autonomous and the cultural models:

An 'autonomous' model of literacy or numeracy assumes that the skills of reading, writing, enumerating, and 'doing math' are independent of social context, have 'autonomous' characteristics that are universal across time and space, and generate consequences-for cognition, social progress and individual achievement-that are general rather than cultural specific. The 'cultural' model sees reading, writing, enumerating, and 'doing math' as social practices, learnt in specific cultural contexts and imbued with epistemological significance. In this model, the uses and meanings of literacy and numeracy cannot easily be generalised across cultures but have to be understood in their context.[...] such practices and concepts are always implicated in power relations and contests over meanings and resources. (p. 79)

Even though both models are discussed, the autonomous view dominates the domain of educational policy and education. Nevertheless, it is important to note that the autonomous perspective on literacy and numeracy is influenced by the societal and political context. Baker and Street (1996) argued that contemporary academic mathematics' claims (in universities and schools) are founded upon universal truths and techniques. In their view, this privileges particular subsectors of society, often to the disadvantage of cultural minorities. They also noted, with reference to Mellin-Olsen (1987), that in many societies, numeracy plays a role as a gatekeeper regarding employment (Baker and Street 1996). Therefore, Street (1992) differentiated between dominant literacies and everyday literacies, a model which has later been applied to numeracy (Baker and Street 1996).

In order to analyse numeracy as social practice, we distinguish between events and practices, which is similar to the analysis of literacy as social practice. The term 'literacy event', meaning "any occasion in which a piece of writing is integral to the nature of participants' interactions and their interpretive processes", was first developed by Heath (1982). The concept of 'literacy practices' based on literacy events includes aspects such as performance, conceptualisations, and intentions concerning the use and meaning of reading and/or writing. Additionally, they are based on everyday theories (folk models; Street 1993) and ideological preconceptions (Street 1984, 1993).

In our study, firstly we take into account the social domains in which the events/practices are embedded and to which they relate. Social domains are specifically structured; they are more or less determined by established structures of society and define spaces within which people act and to which they respond. We already used this kind of perspective in an earlier ethnographical study on literacy as a social 
practice (Zeuner and Pabst 2011). Secondly, our approach is based on a specific theoretical framework, referring to a subject-oriented perspective (Holzkamp 1993; Allespach and Held 2015), while analysing numeracy as social practice. Within this framework, researchers consider the viewpoints of individuals and their interpretations of meanings. Relevant for this approach are individual objectives of action and structures of meaning, in which, among other things, social power relations are reflected.

Therefore, when speaking about numeracy practices, we refer to a broader understanding than just 'doing' numeracy. Firstly, we consider the event in which a certain numerical activity is involved. Secondly, we consider the broader cultural conceptions that give meaning to the event. Thirdly, while analysing practices, we also take into account the personal meaning or the relevance people attribute to their numeracy performance. Fourthly, our analysis considers relevant social and political contexts.

In addition, our study focuses on the role numeracy has played in the lifespan of our interviewees biographically. Thus, in our interviews we asked how and why the interviewees used and use mathematical thinking, skills, competences, modelling, and so on in their everyday life. With the help of the different facets of numerate behaviour as defined in the PIAAC framework, numeracy practices can be systematised in detail. However, from our theoretical point of view, we aim at identifying and describing various numeracy practices of older people, foremost taking into account individual as well as social meanings to which they refer, while applying these different numeracy practices. Therefore, we are not asking for certain skill levels or mathematical knowledge per se, even though they might be identified or referred to in the course of data analysis and interpretation.

\subsection{Vulnerability}

Vulnerability, our second theoretical approach, refers to an analytical concept initially used in environmental sciences to study the human impact of natural disasters such as floods, earthquakes or droughts (Schröder-Butterfill et al. 2006). Other disciplines, like clinical psychology, health psychology, and medicine, also claim the term 'vulnerability'. Vulnerability or susceptibility to disease can be interpreted as a result of the interaction of risk factors such as genetic makeup, lifestyle, certain life conditions, as well the spatial and social environment (Kruse 2017).

According to Streich (2009), vulnerability increases due to (un)social conditions, deficiency situations, and adverse living conditions such as housing shortages, unemployment, social discrimination, etc. Shi et al. (2008) stated that vulnerable populations are not only affected by one set of risks but by several risk factors. Similarly, a Swiss study suggests a much broader view on vulnerability. In addition to medical and psychological perspectives, the economic and social situation of a person is also seen as being prone to vulnerability (Gasser et al. 2015). All perspectives highlight that vulnerability and insecurity contribute to the fact that people are more susceptible to stress and lack sufficient coping strategies to counter threats (Chambers 1989). However, not everyone is equally vulnerable to threat: the way the threat is handled influences whether people are more or less vulnerable to harm (Schröder-Butterfill et al. 2006). Furthermore, Chambers (1989) stated that "Vulnerability has thus two sides: an external side of risk, shocks and stress to which an individual or household is subject; and an internal side which is defencelessness, meaning a lack of means to cope without damaging loss" (p. 1). We refer to vulnerability in a broader sense and include dimensions such as the economic and financial situation, health, and social embeddedness (see below). We argue that older people are more likely to be exposed to certain risks such as poor health or economic and financial constraints which may lead to social isolation or exclusion. As a result, older people may become more vulnerable.

If older people are regarded as vulnerable, they may be characterised as being poor, frail or lonely (Russell 1999). In this context, Schröder-Butterfill et al. (2006, p. 1) raised the questions: "What is it a person is vulnerable to?" and "Who defines vulnerability?" According to Kruse (2017), possible weaknesses in old age can be described by the term 'vulnerability'. However, the author does not directly refer to certain diseases, functional losses, and impairments but rather takes into account the increasing susceptibility of older people to such conditions. As a further risk, the loss of so-called assistance is mentioned: this means that in addition to physical and cognitive demands and strains, emotional vulnerability will also increase (Kruse 2017). Further dimensions such as the level of education and health education, material resources, location and quality of housing, accessibility and the quality of services like care or social networks also determine degrees of vulnerability. How people are able to cope with vulnerability also depends on these resources, which are biographically and socially linked. According to Gasser et al. (2015), differences concerning these dimensions tend to increase with age: "Vulnerability is therefore characterised by a cumulative deficit (...). Vulnerable older people not only often lack money, but also live isolated, struggle with language and understanding difficulties, and are restricted in their mobility" (p. 5).

The greater the number of these aspects that apply to older people, the higher the risk of becoming vulnerable. We are aware of the fact that vulnerability does not apply to all people of advanced age. According to the literature, the three dimensions financial and economic situation, health, and social embeddedness seem to increase the likelihood of older 
Table 1 Sociodemographic status data of the interviewees

\begin{tabular}{|c|c|c|c|}
\hline Interview & Sex & Age (years) & Vocational education, jobs, professional activities \\
\hline Interview 01 & Male & 84 & Retail salesman in the office furniture industry; office technology; bookkeeping \\
\hline Interview 02 & Female & 64 & $\begin{array}{l}\text { Office clerk; bookkeeping at an insurance company and an engineering association; personnel department } \\
\text { of a transport company }\end{array}$ \\
\hline Interview 09 & Male & 92 & Commercial assistant; innkeeper; warehouse worker (food production) \\
\hline Interview 10 & Female & 68 & $\begin{array}{l}\text { Pharmacy assistant; switchboard operator; bookkeeper; radio editor of the Lutheran Church in Northern } \\
\text { Germany; administrative duties for the synod of the Lutheran Church in Hamburg; memory coach }\end{array}$ \\
\hline
\end{tabular}

people becoming vulnerable. We also find these dimensions in our interviews, which thus support the argument.

\section{Methodological approach: qualitative inquiry}

Our overall study entitled 'Numeracy as social practice in the course of time' explores everyday numeracy practices of the war and post-war generation (born between 1926 and 1955). We are investigating how people, who are beyond school and adult education, deal with mathematical problems. We are interested in the personal strategies they have developed in order to solve them. We also ask how they apply numeracy practices in everyday life, with respect to the meaning of these numeracy practices as well as their individual biographical significance. In addition to researching historical arithmetic artefacts (texts) from 1920 onwards, we conducted 11 short interviews with randomly chosen people between the ages of 15 and 84 years in Hamburg-Barmbek (duration between 5 and $10 \mathrm{~min}$ ) in order to explore the access to the field.

Based on these data and our view on numeracy as social practice, we developed a guideline for in-depth focused interviews with older people. This form of guided interview correlates with the interpretative paradigm of qualitative research in the social sciences (Hopf 2015). The investigation is designed in such a way that different perspectives as well as individual orientations and positions can be included, which can additionally offer the chance of a discursive understanding of different and alternative interpretations of the object of research (Hopf 2015).

Between June and November 2018, we conducted ten interviews with people aged 64 to 93 years (duration between 47 and $120 \mathrm{~min}$ ), chosen to achieve our goal to study individual numeracy practices of older people (age cohort 65 and above). They were recruited in different ways, mainly by presenting our project at meetings for the elderly at churches, the Red Cross, a local community college, etc., and also by 'word of mouth' recommendation. The interviewees supported our project voluntarily. These interviews focused on numeracy practices in everyday life, on biographical aspects, and on individual views and social requirements regarding the application of numeracy practices. Numeracy in relation to vulnerability - the topic of this article-was not central to our questions. Nevertheless, in four out of the ten interviews, we found an extraordinary number of statements about numeracy practices in combination with vulnerability and about the interdependencies between vulnerability in old age and the usage of numeracy. Since these findings correspond strongly with the overall topic of the issue of this journal, we decided to analyse these four interviews separately, focusing on the aspect of vulnerability in old age and numeracy as social practice.

Table 1 shows the sociodemographic status of the four selected respondents whose interviews we included in the scope of this paper.

The analysis of the interviews was carried out using the coding process of grounded theory according to Strauss and Corbin (1996). It is a systematically reasoned procedure which makes it possible to obtain and analyse various types of data openly and flexibly. Data analysis and theory generation are interdependent and mutually dependent. On another occasion, we described the associated research process as spiral-shaped, since it is based on recurring phases of data interpretation and withdrawal from already existing theoretical knowledge (Zeuner and Pabst 2011). Using grounded theory as a methodological approach, we could generate a data-based theory of intermediate range by systematically and repeatedly comparing our data, using the central method of open, axial, and selective coding. The resulting codes can be located more strongly in theory (theoretical codes) or in the data (in vivo codes) (Strauss and Corbin 1996).

Using this method, we first analysed the four selected interviews methodically according to numeracy events and practices. In the second step, we systematically arranged them, inspired by our theoretical framework. Our generated categories consist of core categories, which we have borrowed from categories in the literature (see Sect. 3). The subcategories show numeracy practices related to vulnerability in old age, which are of particular importance to respondents in their daily lives. According to grounded theory, the category system used is both an analytical tool and a first result. Table 2 shows the categories generated. 
Table 2 Category system for the four selected interviews

\begin{tabular}{|c|c|}
\hline Vulnerability in old age & $\begin{array}{l}\text { Numeracy practices interrelated to vulner- } \\
\text { ability }\end{array}$ \\
\hline $\begin{array}{l}\text { Financial and economic } \\
\text { situation }\end{array}$ & $\begin{array}{l}\text { Households with the statutory pension and } \\
\text { private old-age provision } \\
\text { Saving and building up reserves } \\
\text { Personal budgeting and private bookkeep- } \\
\text { ing }\end{array}$ \\
\hline Health & $\begin{array}{l}\text { Medical and therapeutic measures } \\
\text { Health problems and individual financial } \\
\text { situation } \\
\text { Individual coping strategies for mental } \\
\text { strength } \\
\text { Critical perspectives on health issues }\end{array}$ \\
\hline Social embeddedness & $\begin{array}{l}\text { Financial independence and maintaining } \\
\text { important social contacts } \\
\text { Advice and support for other people } \\
\text { Participation in specific courses and other } \\
\text { events using numeracy practices }\end{array}$ \\
\hline
\end{tabular}

\section{Results: reciprocal effects concerning vulnerability and numeracy in old age}

In the following section we present the results, analyse the reciprocal effects of vulnerability and numeracy in old age, and interpret the above-mentioned categories.

\subsection{Financial and economic situation}

Although we did not directly ask our interviewees about their financial situations, we nevertheless received insights into the topic. In talking about everyday mathematics, they explained how they deal with money in order to make ends meet and how their pensions and other financial matters affect their daily lives. In the selected interviews, numeracy events and practices became visible and linked individual meaning to the retirement status:

- Households with the statutory pension and private oldage provision.

- Saving and building up reserves.

- Personal budgeting and private bookkeeping.

In Germany, the statutory pension is the predominant source of income in old age (Bäcker and Schmitz 2013), a fact mirrored in our interviews. Due to political power relations, decisions concerning pensions have been subject to multiple changes, dominated by the fact that the financial situation of people over time will worsen rather than improve. This aspect of the social and political embeddedness of people's personal budgets is mirrored in our interviews. The pensions of three interviewees are quite low and managing the budget requires adequate, long-term strategies. Therefore, the topic of private pension provision was relevant for two interviewees. Interviewee 2 decided early on to take on a private pension plan, since she entered the labour market comparatively late and often worked in lowpaid jobs. In contrast, Interviewee 1 saw no need for special provision since he inherited some money which he takes special care of, though "with anger, because no penny is added to it" (Interview 1, p. 28). ${ }^{2} \mathrm{He}$ stated that despite these additional sources of income, careful spending of the money available is required.

Both interviewees use mathematical skills such as calculating and estimating in order to make ends meet. However, they also apply long-term strategies using numeracy practices to anticipate changes. Two interviewees feel compelled to save money, while developing different strategies: Interviewee 9 restricts his daily shopping to the most necessary goods; Interviewee 2 plans her savings well in advance. By selling her car, moving into a smaller, cheaper flat, and borrowing books instead of buying them, she succeeds in minimising costs in the long run. However, she does not perceive these measures as a restriction of her quality of life, since she can still enjoy her life as a pensioner.

Interviewee 2 reports how, in addition to saving, she builds up reserves in order to cover running costs:

So that I didn't get into a spin or something, I then came up with a scheme so that I could basically tell today what I had left at the end of the month, what was actually in the account, and then I always checked it and so on. Yes, I always looked at the costs that were incurred. Insurances or something like that. How much they are per year; how much they are per month. This monthly contribution I monthly transferred to the account and therefore, as far as reserves were concerned, I never got into trouble, because I always had the money when it was due. (Interview 2, p. 2)

The numeracy practices she describes enable her to apply mathematical skills like calculating and estimating and planning costs in advance. Her planning is proof of her ability to adapt to new, challenging changes using numerate behaviour (see PIAAC). Additionally, this kind of planning indicates aspects of critical numeracy: the person is able to critically assess the overall economic situation and political conditions which, at least in the future, might influence her financial situation negatively. Anticipating these developments, she changes her numerate behaviour. However, her action as she describes it does not include a critical analysis of the politics concerning pensions in the long run. She anticipates changes

\footnotetext{
$\overline{2}$ The translation of the interview quotes was done by the authors.
} 
on a personal level and acts accordingly but does not engage politically.

Three of the four interviewees regularly monitored their personal budgets in order to supervise their spending effectively, even before they retired. One interviewee describes the procedure for creating the record:

I do this every week. I collect my receipts. I get a receipt for everything, even if it's not 'in vogue', I'm not really interested in that. I enter everything and only keep the receipts that have something to do with guarantees or where I have to provide something - that can happen sometimes. Yes, I do that weekly. (Interview 10, p. 22)

By collecting receipts from daily purchases, the interviewee gets an overview of her expenses and takes note of them regularly. This behaviour first of all describes numeracy events, i.e., 'doing numeracy'. In order to perform the events, some interviewees apply computational skills, using a PC and an Excel spreadsheet or other software. The budget books not only document daily costs, but they also provide a financial framework which allows them to compare income and expenditure. Writing a budget book using mathematical skills and ideas therefore becomes an individual numeracy practice which gives subjective meaning to this task (Interview 2; Interview 10). In addition to creating a household book, Interviewee 1 also performs a kind of private accounting for himself. Using his accounts, he meticulously determines the surpluses and losses and thus checks any incorrect entries. As with the budget book, the control of bank accounts in conjunction with accounting also serves to keep track of one's own finances and to avoid unnecessary expenditure (see interview partner 10). Skills according to the PIAAC are applied when numbers are read and related.

\section{Health}

Health issues were addressed in different ways - directly and indirectly. Directly, the interviewees talked about individual health restrictions (e.g., hypertension, renal insufficiency, cancer, heart attack, hip surgery) and their consequences, or explained personal strategies for responding and handling these restrictions. Four dimensions concerning the combined topics of health, age, and vulnerability could be identified in the data numeracy events and practices:

- in relation to health numeracy

- in relation to health problems and individual financial situation

- in relation to individual coping strategies for mental strength

- for critical perspectives on health issues.
Current health restrictions and appropriate medical treatment are closely linked. These are major aspects when considering people of old age as a risk group prone to physical vulnerability (Renteln-Kruse 2008; Kruse 2017). In our interviews, numeracy events or practices are described as the regular intake of various medications or the evaluation of health restrictions in view of various laboratory and examination findings. These evaluations involve statistical analysis as well as basic medical knowledge combined with the ability to critically assess results in relation to one's own health. Therefore, mathematical knowledge and skills such as calculation, counting, measuring, and estimation have to be applied in order to interpret the data and communicate with medical staff_-doctors, nurses, and support staff and to come to informed decisions concerning treatments and therapy options.

In addition, we find different numerical practices which control specific behaviour or everyday routines that serve individual health benefits. These include individual time management or measurement-for example, controlling fluid intake, performing specific exercises in order to stimulate physical activity, or generally following an individual work-life balance regime. Failing or declining memory is often an issue among older people, and they develop different numeracy strategies to cope with it, such as, for example, training memory skills while calculating prices or expenditures.

The anticipation of health problems and their prevention is often closely linked to financial expenses. One interviewee reports on her long-term saving strategy in order to be able to afford the next pair of glasses:

[...] and with this calculating, it also helps to keep the overview and just to look like that or, for example, at some point I'll need a new pair of glasses which will be very expensive. And as a retired person I can't just shake it up my sleeves. So I asked myself, how much is it today? About 1,000 euros. And then I thought, when is the next pair due? Five years. Then 1,000 euros divided by five and then again divided by the year-how much do I have to save every month? And so I actually handle all the things (expenditures) for the big things. (Interview 2, p. 11).

Someone else explains a complicated procedure for claiming one-year reimbursement from his health insurance company for private copayments for prescription drugs. To benefit from this, he has to prove the yearly expenses, for which he uses accounting software.

Numeracy practices are also applied as individual strategies in order to cope with the potential health restrictions and ageing itself. Health issues become significant in old age, since they are not only closely related to physical wellbeing but also relate to opportunities to participate in social 
life, to be able to live a self-determined and autonomous life, and to experience individual life satisfaction (Kruse 2017).

All interviewees addressed these aspects, expressing their opinions and explaining their coping strategies in order to stay mentally active and flexible. In this context, numeracy practices become crucial, in that groceries are added up mentally, cooking recipes are converted, telephone numbers are memorised, friends are met regularly to play card games, etc. It is emphasised that these activities are performed purposefully and without further aids.

These strategies become particularly clear in the interview with the memory coach (Interview 10). This interviewee tells about her different ways of integrating mental arithmetic and therefore applying mathematical skills to everyday life events in order to stay mentally active and flexible. The daily use of the computer helps another interviewee to maintain his current cognitive ability (Interview 1). An interviewee, who is no longer mobile and stays in his apartment most of the time reports as follows:

I feel I have to develop it further and I can't just stand there and say, now I don't care anymore. ... As a child, you've already heard that from the old people: don't let yourself go, be agile as long as you can breathe, you have to do something. And don't say, now I don't feel like it anymore. (Interview 9, p. 12).

These examples show the interrelation between health, self-care and autonomy, as well as its significance in old age (Doyal and Gough 1991; Wiggins et al. 2004).

Some of our results can also be viewed from a critical perspective of numeracy. Numeracy practices are used to assess health conditions critically, such as weighing and evaluating surgical interventions or strategically handling the limited time of nursing staff. One interviewee describes the decision-making process concerning hip surgery, for which the attending physician advised him to keep a pain protocol to document the intensity of pain in everyday life. In the course of time, the interviewee has increasingly differentiated this protocol, for example with records of medication, blood pressure measurement, physical activity, etc., in order to be able to make a more detailed assessment of the pain:

One is no pain, ten is unbearable. [...] That's how it is. And everything that happened about it. I recorded that. I don't know if I still have it at home. Most of the time I still have it. This has become a real treatise and they just marvelled and said: 'Golly'. Then the main physician came in and I had another whole hour or more with him and then I said 'yes' at the end. (Interview 1, p. 42).
This relates to suggestions concerning health numeracybeing able to make appropriate health decisions and monitoring one's own health (see Sect. 3.2).

\subsection{Social embeddedness}

As stated in Sect. 3.2, vulnerability in old age is often considered in relation to social inclusion or exclusion or in the context of social embeddedness of the elderly (Hawkley 2017) and discussions concerning these aspects are numerous. The theoretical frameworks range from a social needs perspective and a cognitive perspective to an evolutionary perspective (Hawkley 2017). In the different approaches, various factors such as social or emotional loneliness, poor social integration, feelings of disconnection, negative expectations, or anxiety are considered as being antagonistic to social embeddedness. Hawkley (2017) refers to different quantitative studies, discussing interrelations between loneliness, social inclusion/exclusion in old age in relation to certain dimensions such as gender, socioeconomic status, health, stressful events, and social relations (see also Bessa et al. 2018). Whereas the impact of gender seems to be uncertain, other factors such as socioeconomic status, health, stressful events, and social relations seem to play an important positive role concerning social embeddedness. Higher socioeconomic status, better health, and reliable social relations seem to foster social embeddedness.

Considering these results, our data also provide insights concerning the importance of social embeddedness for older people. Since factors such as financial constraints or serious health issues can lead to a lack of social contacts and therefore isolation, existing or newly developed social networkswith family, friends, neighbours, social groups, professional caregivers and the like - are crucial for older people (Gasser et al. 2015; Kruse 2017). The following categories refer to reciprocal effects concerning social embeddedness, numeracy practices and vulnerability:

- Financial independence as a prerequisite for maintaining important social contacts

- Advice and support to others on financial issues, computer problems, etc.

- Participation in specific courses and other events using numeracy practices.

Social embeddedness involves various forms of interaction and communication, and activities with others and for others. Regardless of the age of our interviewees, we find evidence that financial independence and autonomy are important in order to maintain social contacts, hobbies, etc., with the aim of living independently for as long as possible. Plans and considerations are made regarding one's financial situation in relation to shaping one's life in the third phase 
(personal goals, hobbies, friends and family). We find strategies concerning the transition to retirement where financial restrictions lead to personal budgeting plans.

Some interviewees function as competent partners and counterparts in discussing numerical problems and finding solutions with families and friends. Thus, they gain social recognition which is important for personal identity and selfconfidence in old age. At least two interviewees talk about counselling family members or caregivers or supporting family members financially (Interview 1 and 9). Different activities in old age serve to maintain social contacts. They include numerical practices in the narrower as well as in the broader sense. Examples in our interviews are the following: regular visits of Skat rounds (poker-buddies), participation in mental training courses, asking others for specific support-for example helping with computer problems, and conversations with family members about new digital applications.

\subsection{Discussion of findings}

Our findings concerning interdependencies of vulnerability and numeracy practices in relation to old age confirm reciprocal effects of the usage of numeracy practices and numerical skills by older people in order to minimise vulnerability. Considering our research questions (Sect. 1), we find positive results concerning the interrelationship between old age, financial and economic situations, health, social embeddedness and numerate behaviour and the risk of vulnerability. We find that the numeracy practices that our interviewees are applying correspond more to the cultural or ideological model of Street and Baker (1996) than to the autonomous model, since the interviewees are using and developing them according to their personal needs and living conditions. They perform numeracy events and practices within the context of old age, health, and vulnerability. This aspect also corresponds with the findings of the CiLL study which stated that older people are using numeracy practices rather than applied mathematical skills (see Sect. 2.3).

Concerning the financial and economic situation, our interviewees show different strategies into order to cope with expected financial constraints. This aspect strongly relates to observations in the literature in which the rethinking of financial issues with respect to retirement becomes important. The topic of finances thus determines the everyday lives of our interviewees and holds important meaning for them, enabling to them to live well in old age according to their individual ideas and means (Houston 2009). Even though the interviewees do not use the term 'vulnerability' themselves, they are aware of the risk of becoming financially vulnerable in old age. This is indicated by their numeracy practices, which stabilise or even improve their financial situation in old age in order to minimise the risk of financial vulnerability.

Concerning health numeracy, the findings relate to theoretical considerations regarding the ability to monitor and deal with health problems and related issues (Peters et al. 2013). They integrate numeracy practices in their everyday routines while monitoring their health. Therefore, numeracy practices can be seen as an instrument to understand and treat health issues from both a medical point of view and the patient's/old person's perspective. Numeracy practices prove to be significantly important in relation to cognitive training, in order to avoid cognitive impairment and prevent other health issues.

As can be seen, health numeracy also relates to aspects of health politics, which in Germany regulate expenditures in certain ways, restricting possible expenses paid by health insurance companies, etc. The numeracy practices of some of the interviewees mirror these social practices embedded in the health system. But, similarly to the results concerning financial aspects of numeracy practices, the interviewees do not, in their personal meaningful actions concerning health issues, critically assess the health system as a whole or try to change it politically.

Our interviews also show that social embeddedness leading to social inclusion and avoiding exclusion cannot be singled out as a dimension of old age, but that it is closely related to financial and health aspects (Gasser et al. 2015; Kruse 2017). Good health mobilises people, while a better financial background supports social activities in different ways. Giving reason to individual numeracy practicesevents like calculating and estimating costs, measuring medicine, spending money, interpreting graphs-emphasises the fact that the numeracy practices as social practices are embedded in different cultural settings and contexts (Street and Baker 1996). By applying them, people are both reacting to tasks or expectations and are anticipating developments, while taking into account certain foreseeable biographical changes.

Our interviews also mirror aspects of numerate behaviour as described in the OECD framework of PIAAC (Gal et al. 2009). They show numerate behaviour concerning all aspects mentioned above in order to manage a situation or solve problems such as reading numbers or tables and graphs, counting, performing arithmetic operations (addition, subtraction, multiplication, estimation, or forming relations). In addition, they use also emergent decision-based numeracy abilities, such as recalling numerical information from memory or using it in complex relations (Peters et al. 2013). Some examples also show that numeracy practices are strongly interwoven into everyday life.

Based on our theoretical framework, however, our foremost interest is in analysing the subjective reasons for our interviewees applying certain problem-solving strategies, 
while at the same time referring to subjective reasoning, intentions, and personal needs in performing different aspects of numerate behaviour.

\section{Conclusion}

In our paper we have focused on questions concerning interdependencies and reciprocal effects of numeracy practices, vulnerability, and old age. Our findings demonstrate different interrelations concerning the usage and application of numeracy practices based on mathematical knowledge and skills by older people in order to overcome obstacles in everyday life situations such as financial constraints or risks, health issues, or social isolation and exclusion. Concerning the concept of numeracy as social practice, it becomes obvious that most of the numeracy practices our interviewees are performing are justified by subjective reasoning, intentions, and personal needs.

Therefore, the application of numeracy practices is done intentionally and purposefully. In applying numeracy events in order to reach certain objectives, our interviewees sometimes draw on mathematical skills and competences which they learned in the formal educational system, the workplace, or somewhere else. However, most of their numeracy practices indicate that the mathematical knowledge and competences they apply were developed individually in autodidactic, self-directed learning settings, using routines and patterns of action resembling the concept of numerate behavior and coinciding with the finding of the CiLL study (Knauber and Weiß 2014; see Sect. 2.1). They link applications of mathematical skills with life experience, world views, and knowledge concerning political, societal, and economic developments, which influence their personal lives. They are able to assess political and economic developments critically, and to relate them to their own living conditions in the sense of critical numeracy (Yasukawa 2018; see Sect. 2.3). The applied numeracy practices are culturally embedded in the society from which the interviewees come and are therefore unique. Different cultural environments and backgrounds would lead to insights into different numeracy practices.

Since our data indicate the cultural embeddedness of numeracy practices, the question arises of how this could be integrated in basic adult numeracy education. Reviewing and reflecting on the few existing curricula focusing on basic numeracy education (Kaiser 2009; DVV 2017) or financial literacy (DIE 2015; Mania and Tröster 2015) in Germany and Switzerland, we mostly find traditional, skill-oriented mathematical modelling, implying a deficitperspective concerning the skills and knowledge of the learner. The question of the everyday use and application of numeracy practices is rarely tackled.

From the perspective of older people like our interviewees, however, creative ways of dealing with everyday problems requiring different numeracy practices are employed. Therefore, we ask how the concept of culturally induced numeracy practices could be integrated in the respective basic numeracy curricula. From our point of view, it is important for facilitators to recognise already existing skills and knowledge. This recognition implies a change of perspective from a deficit-oriented view to a resource-oriented view concerning (older) adult learners. The curricula could gain more impact if more attention were paid to the fact that most people have developed their own numeracy practices and are able to use them creatively and according to their own needs. These practices should be appreciated in their own right. They mirror non-formal competences which are 'unmeasurable', sometimes untraceable and invisible, but nonetheless existent. They fulfil tasks for people according to their own needs and objectives, and the respective contexts are recognised in their own right. They have reciprocal and interrelated effects and impacts, are influenced by different parties, each having their own agenda, and are affected by interests and power relations.

In addition, the concept of "critical numeracy practices' (Yasukawa 2018) should be taken into account when reconsidering basic numeracy curricula in adult education, with a goal of developing the ability of people to reflect on future personal needs and aspirations in relation to society's expectations and the opportunities that society offers. In order to apply numeracy practices for one's own good, people should develop a critical view about the economy and finances in relation to future needs. This aspect includes aspects of a critical economic competence which will allow people to understand and assess economic developments with regard to broader political objectives, as well as in relation to their personal aims later in life concerning financial issues, education, pension, healthcare, housing, nutrition, and so on.

For us, this leads to the question of how people could become aware of the fact that mathematical skills and numeracy practices involve more than mental operations and methods but concern real-life questions which are simultaneously culturally embedded and reflect the fact that they can be used for political and social transformation within the scope of an informed, critical, and reciprocal dialogue within society.

Acknowledgements Open Access funding provided by Projekt DEAL. 
Open Access This article is licensed under a Creative Commons Attribution 4.0 International License, which permits use, sharing, adaptation, distribution and reproduction in any medium or format, as long as you give appropriate credit to the original author(s) and the source, provide a link to the Creative Commons licence, and indicate if changes were made. The images or other third party material in this article are included in the article's Creative Commons licence, unless indicated otherwise in a credit line to the material. If material is not included in the article's Creative Commons licence and your intended use is not permitted by statutory regulation or exceeds the permitted use, you will need to obtain permission directly from the copyright holder. To view a copy of this licence, visit http://creativecommons.org/licenses/by/4.0/.

\section{References}

Allespach, M., \& Held, J. (2015). Handbuch Subjektwissenschaft. Ein emanzipatorischer Ansatz in Forschung und Praxis. Frankfurt/M.: Bund-Verlag.

Bäcker, G., \& Schmitz, J. (2013). Altersarmut und Rentenversicherung: Diagnosen, Trends, Reformoptionen und Wirkungen. In C. Vogel \& A. Motel-Klingebiel (Eds.), Altern im sozialen Wandel: Die Rückkehr der Altersarmut? (pp. 25-53). Wiesbaden: Springer.

Baker, D., \& Street, B. (1996). Literacy and numeracy models. In A. Tuijnam (Ed.), International encyclopedia of adult education and training, 2 edn (pp. 79-85). Oxford: Pergamon Press.

Barton, D., \& Hamilton, M. (1998). Local literacies: Reading and writing in one community. London: Routledge.

Bessa, B., Ribeiro, O., \& Coelho, T. (2018). Assessing the social dimension of frailty in old age: A systematic review. Archives of Gerontology and Geriatrics, 78, 101-113. https://doi. org/10.1016/j.archger.2018.06.005.

Borba, M. C. (1990). Ethnomathematics and education. For the Learning of Mathematics, 10(1), 39-43.

Bynner, J., \& Parsons, S. (2006). New light on literacy and numeracy. London: National Research and Development Centre for Adult Literacy and Numeracy.

Chambers, R. (1989). Vulnerability, coping and policy. IDS Bulletin, 20(2), 1-7.

Cockcroft, W. (1982). Mathematics counts. London: HMSO.

D’Ambrosio, U. (1999). Literacy, matheracy, and technoracy: A trivium for today. Mathematical Thinking and Learning, 1(2), 131-153.

Deutsches Institut für Erwachsenenbildung (DIE). (2015). Projekt CurVe. The Financial Literacy Competence Model. Bonn: DIE. https://www.die-bonn.de/curve/content/PDF/DIE_Kompetenzm odell_engl.pdf. Accessed Sept 28, 2019.

Doyal, L., \& Gough, I. (1991). A theory of human need. London: Macmillan.

Ernest, P. (2002). Empowerment in mathematics education. Philosophy of Mathematics Journal. https://citeseerx.ist.psu.edu/viewd oc/download?doi=10.1.1.4.9516\&rep=rep1\&type=pdf. Accessed April 17, 2019.

Friebe, J., \& Schmidt-Hertha, B. (2013). Activities and barriers to education for elderly people. Journal of Contemporary Educational Studies/Sodobna Pedagogika, 64(1), 10-26.

Friebe, J., Schmidt-Hertha, B., \& Tippelt, R. (Eds.). (2014). Kompetenzen im höheren Lebensalter. Ergebnisse der Studie "Competencies in Later Life" (CiLL). Bielefeld: Bertelsmann.

Gal, I., Alatorre, S., Close, S., Evans, J., Johansen, L., Maguire, T., Manly, M., \& Tout, D. (Eds.). (2009). PIAAC numeracy: A conceptual framework (OECD Education Working Paper No. 35). Paris, France: OECD. https://files.eric.ed.gov/fulltext/ED530713. pdf. Accessed September 27, 2019.

Gasser, N., Knöpfel, C. H., \& Seifert, K. (2015). Erst agil, dann fragil. Übergang vom ‘dritten' zum ‘vierten' Lebensalter bei vulnerablen
Menschen. https://www.prosenectute.ch/de/dienstleistungen/publi kationen/studien/erst-agil-dann-fragil.html. Accessed April 17, 2019.

Geiger, V., Goose, M., \& Forgasz, H. (2015). A rich interpretation of numeracy for the 21st century: A survey of the state of the field. ZDM-The International Journal on Mathematics Education, 47, 531-548. doi:10.1007/s11858-015-0708-1

Gerdes, P. (1994). Reflections on ethnomathematics. For the Learning of Mathematics, 14(2), 19-21.

Hawkley, L. (2017). Loneliness and social embeddedness in old age. In N. Pachana (Ed.), Encyclopedia of geropsychology (pp. 14321438). Singapore: Springer.

Heath, S. B. (1982). What no bedtime story means: Narrative skills at home and at school. Language in Society, 11(1), 49-76.

Holzkamp, K. (1993). Lernen. Subjektwissenschaftliche Grundlegung. Frankfurt/M.: Campus.

Hopf, C. (2015). Qualitative interviews-ein Überblick. In U. Flick, E. Kardorff, \& I. Steinke (Eds.), Qualitative Forschung: Ein Handbuch (pp. 349-360). Reinbek bei Hamburg: Rowohlt Taschenbuch Verlag.

Houston, S. (2009). The concept and measurement of financial literacy: Preliminary results from a new survey on financial literacy assessment. Conference Presentation, Academy of Financial Services Annual Conference. Anaheim, CA, October 9.

Hoyles, C., Noss, R., Kent, P., \& Bakker, A. (2010). Improving mathematics at work: The need for technomathematical literacies. London: Routledge.

Institute of Medicine. (2014). Health literacy and numeracy: Workshop summary. Washington, DC: The National Academies Press. https ://doi.org/10.17226/18660. Accessed Sept 28, 2019.

Kaiser, H. (2009). Bausteine für ein Konzept zur Förderung alltagsmathematischer Kompetenz. Zürich: Schweizerischer Verband für Weiterbildung.

Knauber, C. \&. Weiß, C. (2014). Alltagsmathematische Kompetenz. In Friebe, J., Schmidt-Hertha, B., \& Tippelt, R. (Eds.), Kompetenzen im höheren Lebensalter. Ergebnisse der Studie "Competencies in Later Life" (CiLL) (pp. 81-96). Bielefeld: Bertelsmann.

Kruse, A. (2017). Lebensphase hohes Alter: Verletzlichkeit und Reife. Berlin: Springer.

Lave, J. (1988). Cognition in practice: Mind, mathematics and culture in everyday life. Cambridge: Cambridge University Press.

Mania, E., \& Tröster, M. (2015). Finanzielle Grundbildung. Programme und Angebote planen. Bielefeld: W. Bertelsmann Verlag. doi: $10.3278 / 43 / 0049 w$

Mellin-Olsen, S. (1987). The politics of mathematics education. Dordrecht: Reidel.

Paulos, J. A. (2000). Innumeracy: Mathematical illiteracy and its consequences. London: Penguin.

Peters, E., Meilleur, L., \& Tompkins, M. K. (2013). Numeracy and the Affordable Care Act: Opportunities and challenges. Paper commissioned by the Roundtable on Health Literacy, Institute of Medicine. https://nationalacademies.org/hmd/ /media/Files/Activ ity\%20Files/PublicHealth/HealthLiteracy/Commissioned-Papers/ Numeracy-and-the-Affordable-Care-Act-Opportunities-and-Chall enges.pdf Medicine. https://doi.org/10.17226/18660. Accessed Sept 28, 2019.

Renteln-Kruse, W. V. (2008). Krankenhausversorgung alter Menschen. In A. Kuhlmey \& D. Schaeffer (Eds.), Alter, Gesundheit und Krankheit (pp. 320-333). Bern: Huber.

Russell, C. (1999). Interviewing vulnerable old people: Ethical and methodological implications of imagining our subjects. Journal of Aging Studies, 13(4), 403-417.

Schröder-Butterfill, E., \& Marianti, R. (2006). A framework for understanding old-age vulnerabilities. Ageing Society, 26(1), 9-35. doi: 10.1017/S0144686X05004423. Accessed Sept 28, 2019. 
Shi, L., Stevens, G. D., Lebrun, L. A., Faed, P., \& Tsai, J. (2008). Enhancing the measurement of health disparities for vulnerable populations. Journal of Public Health Management and Practice, 14(Suppl.), 45-52. doi: 10.1097/01.PHH.0000338386.59565.dc. Accessed Sept 28, 2019.

Straesser, R. (2007). Didactics of mathematics: More than mathematics and school! ZDM-The International Journal on Mathematics Education, 39(1), 165-171.

Strauss, A., \& Corbin, J. (1996). Grounded theory: Grundlagen Qualitativer Sozialforschung. Weinheim: Beltz.

Street, B. (1984). Literacy in theory and practice. Cambridge: Cambridge University Press.

Street, B. (1992). Sociocultural dimensions of literacy: Literacy in an international context. In UNESCO Institute of Education: The future of literacy and the literacy of the future. Report of the Seminar on Adult Literacy in Industrialized Countries (pp. 41-53). Hamburg: UIE.

Street, B. (1993). Introduction: The new literacy studies. In B. Street (Ed.), Cross-cultural approaches to literacy (pp. 1-21). New York: Cambridge University Press.

Street, B. (2001). Literacy and development: Ethnographic perspectives. London: Routledge.

Streich, W. (2009). Vulnerable Gruppen: 'Verwundbarkeit' als politiksensibilisierende Metapher in der Beschreibung gesundheitlicher Ungleichheit. In M. Richter \& K. Hurrelmann (Eds.), Gesundheitliche Ungleichheit. Grundlagen, Probleme, Perspektiven (pp. 301-308). Second edition. Wiesbaden, Germany: VS Verlag für Sozialwissenschaften.

Tout, D., \& Gal, I. (2015). Perspectives on numeracy: Reflections from international assessments. ZDM-The International Journal on Mathematics Education, 47, 691-706. doi:10.1007/s11858-0150672-9. Accessed 28 September 2019.

Deutscher Volkshochschulverband (DVV). (2017). Rechnen. DVVRahmencurriculum. 2nd. Ed. Bonn: DVV. https://www.volks hochschule.de/microsite/grundbildung/unterrichten/Curricula. php. Accessed 28 September 2019.
Vygotsky, L. (1986) Thought and language, revised edition (A Kozulin, trans.). Cambridge: MIT Press.

Watson, J., \& Callingham, R. (2003). Statistical literacy: A complex hierarchical construct. Statistics Education Research Journal, 2(2), 3-46.

Wiggins, R. D., Higgs, P., \& Hyde, M. (2004). Quality of life in the third age: Key predictors of the CASP-19 measure. Ageing \& Society, 24(5), 693-708.

Yasukawa, K. (2018). The workplace as a site for learning critical numeracy practice. In K. Yasukawa, A. Rogers, K. Jackson \& B. Street (Eds.), Numeracy as social practice. Global and local perspectives (pp. 225-240). London: Routledge.

Yasukawa, K., Jackson, K., Kane, P., \& Coben, D. (2018). Mapping the terrain of social practice perspectives of numeracy. In K. Yasukawa, A. Rogers, K. Jackson \& B. Street, B. (Eds.), Numeracy as social practice. Global and local perspectives (pp. 3-17). London: Routledge.

Zaslavsky, C. (1994). Africa counts and ethnomathematics. For the Learning of Mathematics, 14(2), 3-8.

Zeuner, C., \& Pabst, A. (2011). 'Lesen und Schreiben eröffnen eine neue Welt!' Literalität als soziale Praxis-Eine ethnographische Studie. Bielefeld: W. Bertelsmann Verlag.

Zevenbergen, R. (1995). Towards a socially critical numeracy. Critical Forum, 4(1), 82-102.

Zevenbergen, R., \& Zevenbergen, K. (2009). The numeracies of boatbuilding: New numeracies shaped by workplace technologies. International Journal of Science and Mathematics Education, 7(1), 183-206. https://doi.org/10.1007/s10763-007-9104-9. Accessed Sept 28, 2019.

Publisher's Note Springer Nature remains neutral with regard to jurisdictional claims in published maps and institutional affiliations. 